\title{
Educational
}

and

Volume 3 | Issue 2

Instructional

Article 12

Technology

2019

\section{Using Technology Enhanced Learning to Promote the Acquisition of Practical Skills in Occupational Therapy}

Terri Grant

University of Worcester, England UK

Follow this and additional works at: https://encompass.eku.edu/jote

Part of the Occupational Therapy Commons

\section{Recommended Citation}

Grant, T. (2019). Using Technology Enhanced Learning to Promote the Acquisition of Practical Skills in Occupational Therapy. Journal of Occupational Therapy Education, 3 (2). https://doi.org/10.26681/jote.2019.030212

This Educational and Instructional Technology is brought to you for free and open access by the Journals at Encompass. It has been accepted for inclusion in Journal of Occupational Therapy Education by an authorized editor of Encompass. For more information, please contact 


\title{
Using Technology Enhanced Learning to Promote the Acquisition of Practical Skills in Occupational Therapy
}

\begin{abstract}
This paper focuses on the use of game-based technology to effectively choose, prescribe, and safely use equipment, which are vital occupational therapy skills. A three-hour workshop was designed for 42 second year British occupational therapy students across two cohorts. The goal was for students to try out a variety of equipment ranging from small household and kitchen aids to elevating chairs and hoisting equipment. Students used the game-based technology during a class to encourage their engagement with practical aspects of equipment use and fitting. A short, optional survey indicated use of the game-based technology resulted in extremely high student engagement and faculty grading identified previously unnoticed student errors in the learning activity. After this workshop, students could enter practice with critical confidence rather than relying on fieldwork placements to provide adaptive equipment use skills.
\end{abstract}

Keywords

Technology enhanced learning, practical skills, adaptive equipment, occupational therapy, game-based learning

\section{Creative Commons License}

\section{(ब) $\Theta \Theta$}

This work is licensed under a Creative Commons Attribution-Noncommercial-No Derivative Works 4.0 License.

\section{Acknowledgements}

With thanks to the team at GooseChase for creating, and allowing me to write about, their innovative app. 


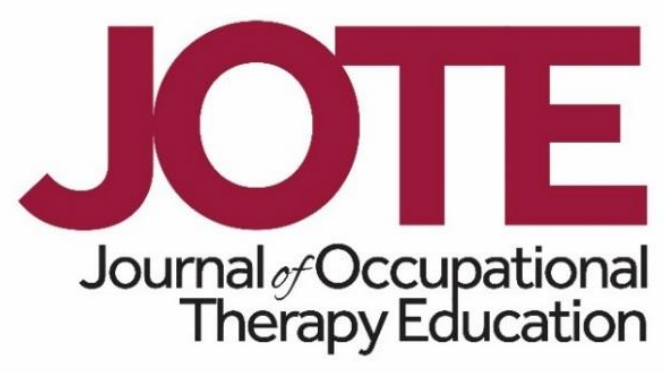

Volume 3, Issue 2

Using Technology Enhanced Learning to Promote

the Acquisition of Practical Skills in Occupational Therapy

Terri Grant, MSc

University of Worcester

United Kingdom

\begin{abstract}
This paper focuses on the use of game-based technology to effectively choose, prescribe, and safely use equipment, which are vital occupational therapy skills. A three-hour workshop was designed for 42 second year British occupational therapy students across two cohorts. The goal was for students to try out a variety of equipment ranging from small household and kitchen aids to elevating chairs and hoisting equipment. Students used the game-based technology during a class to encourage their engagement with practical aspects of equipment use and fitting. A short, optional survey indicated use of the game-based technology resulted in extremely high student engagement and faculty grading identified previously unnoticed student errors in the learning activity. After this workshop, students could enter practice with critical confidence rather than relying on fieldwork placements to provide adaptive equipment use skills.
\end{abstract}

\title{
INTRODUCTION
}

Assessment and prescription of adaptive equipment to facilitate independence is a key role of the occupational therapist in Great Britain (Royal College of Occupational Therapists, 2012). Equipment prescription refers to the process of recommending and, where National Health Service (NHS) or social care funding allows, providing adaptive equipment which the therapist deems necessary to enable occupation and / or reduce safety concerns. Like all practical skills, it takes time and repetition to learn adaptive equipment use, which may not be available in the clinical setting. While many students are exposed to this essential skill during their practice placements, the increasing diversity of placement opportunities means that there is less conformity in what all students can expect to experience on placement (Glenn \& Gilbert-Hunt, 2012; Murray, Turpin, Edwards, \& Jones, 2015). It can no longer be guaranteed that students will 
experience the opportunity to become proficient in equipment fitting before national registration. It is therefore essential that classroom-based learning tackle this aspect of practice, offering students opportunities to explore equipment use in the classroom. This may subsequently support learning on fieldwork placement where time is often limited and students may feel less confident.

Practical skills require an appropriate pedagogical approach that is likely to be different from that taken when teaching theory. Experiential learning approaches and simulation activities are recognized by the Quality Assurance Agency for Higher Education in the United Kingdom (UK) as both transformative and sustainable practices which would appear to be suitable for such learning (QAA, 2014). Developing an appropriate practice environment within the classroom can be challenging due to the preparation time required. Experiential learning can lead students to overlook the theory base if they focus solely on the practical skills (Laurillard, 2010). This paper reviews the blended learning environment (O'Byrne \& Pytash, 2015) created using the freely available GooseChase application (GooseChase, 2018) and the way in which this technology has facilitated development of the required skills in equipment use in a safe and supportive classroom environment.

The terms problem-based learning, social learning, and experiential learning are used throughout this article to describe the pedagogic approaches to learning which use of the technology blends together in order to achieve the most effective learning experience for students. Problem-based learning is a style of learning in which students are faced with a specific problem or case study which they are asked to answer or resolve. The process of finding out how to achieve this resolution dictates the learning achieved (Fry, Ketteridge, \& Marshall, 2003, p. 259). Social learning takes place when students articulate their own and challenge each other's ideas, thus enabling them to reach understanding through discussion (Laurillard, 2010). Experiential learning uses the environment in which the real-life task is practiced to provide feedback to learners. This enables students to understand whether their actions enabled them to achieve the intended goal (Laurillard, 2010).

\section{DESCRIPTION OF THE TECHNOLOGY}

GooseChase (located at https://www.goosechase.com) is best described as a game which enables organizers to plan "scavenger hunts", better known in the UK as treasure hunts. The application is available on Apple, Android and Windows devices. The game is developed in a web browser by the user and comprises a number of "missions" which participants complete in order to win points. GooseChase provides some standard missions, or the user can write their own and ascribe a points value. The missions can be completed by way of a photograph, 10 second video, text entry, or global positioning system (GPS) "check-in" which are received by the organizer in real time, over an internet-connected webpage. A basic version of the application, which enables the user to split participants into five teams, is free for educational use. No specific training of students or staff is required to use the application. Basic digital literacy skills are sufficient for the staff member to set up the game, and it is anticipated that this will become quicker and easier with practice. Students need only to be able to use a 
smartphone, another skill relevant to today's clinical practice (Verdonck \& Maye, 2016) as the interface is smooth and intuitive to use.

\section{LITERATURE REVIEW}

There is a distinct lack of published work relating specifically to teaching methods relevant to equipment prescription in occupational therapy. Searches of CINAHL, MEDLINE and Academic Search Complete between 2008 and 2018 using the terms "adaptive equipment" OR "equipment" AND "occupational therapy" generated no relevant results. No current research was found addressing the use of technology enhanced methods of teaching the practical skills of equipment use. It was reported over a decade ago that the uptake of technology enhanced learning has been slow in the occupational therapy profession (Hollis \& Madill, 2006). Recent focus appears to be limited to the use of online assessment tools, such as e-portfolios (Cordier et al., 2016) and the use of video media, such as digital story-telling (Frost, Isbel, Kellett, \& Lawlis, 2017; Smeda, Dakich, \& Sharda, 2014). However, it is useful to note that colleagues in associated health professions such as nursing have begun to explore the use of virtual teaching tools (Frost et al., 2017; Hardy, Mushore, \& Goddard, 2016) and the occupational therapy profession is moving forward in embracing technology with a rising popularity of social media based content (Manca \& Ranieri, 2017; Murray \& Ward, 2017; Rolls, Hansen, Jackson, \& Elliott, 2016).

Conversely, game-based learning in higher education has gained traction in recent years with a large amount of evidence being generated within the "STEM" subjects of Science, Technology, Engineering and Mathematics (Drummond et al., 2013; Taub, Azevedo, Bradbury, Millar, \& Lester, 2018; Wilson et al., 2018). Crocco, Offenholley, and Hernandez, (2016) reported correlations between enjoyment and deep learning, and suggested that game-based learning could lead to greater levels of enjoyment. There is no evidence to suggest that these core principles should not transfer readily into learning and teaching within occupational therapy. Another area gaining pace within the profession is that of simulation - an educational technique that recreates all or part of a clinical experience (Bennett, Rodger, Fitzgerald, \& Gibson, 2017; van Soeren et al., 2011). Simulation and games can be blended creatively to provide students with the experience of practicing authentic skills within a competitive environment.

Assessment and prescription of equipment is recognized as a significant element of one of the occupational therapy threshold concepts (Nicola-Richmond, Pépin, \& Larkin 2016). Equipment prescription is a complex area of practice which requires a high level of skill and knowledge (Boland, Levack, Perry, \& Graham, 2017), and yet it is often minimized in the classroom curriculum with an expectation that students will gain practical experience while on practice placement. While recognizing that there are many different types of equipment available to the occupational therapist to prescribe, the equipment referred to in this paper can be defined as "An item... which helps people to manage the activities of daily living"(World Health Organization Centre for Health Development, n.d.). 
New graduates report lacking confidence in carrying out practical tasks that they have not adequately experienced in the classroom (Glenn \& Gilbert-Hunt, 2012) and safe equipment prescription is paramount. Without the opportunity to make and correct mistakes being afforded in the classroom, students can struggle to establish appropriate situations in which they can learn about equipment. The challenge, therefore, was to create a blended-learning environment using aspects of problem-based learning, social learning and experiential learning to enable the students to learn about the various uses of equipment in a safe and supported environment.

\section{INCORPORATING GAME-BASED TECHNOLOGY INTO THE TEACHING AND LEARNING PROCESS}

To learn about adaptive equipment, second year occupational therapy students undertook a three-hour workshop using group work to explore a variety of equipment. A GooseChase game was designed to enable students to explore and develop their skills in using and prescribing adaptive equipment available in "Ability House", the dedicated occupational therapy clinical teaching space on campus. Ability House is an adapted property fitted with overhead tracking hoists, stairlifts, level access showering and bathing equipment and an adapted kitchen. It is also home to multiple aids, mobile hoists, toilet equipment, wheelchairs, sensory integration equipment and assistive technology items.

The game comprised 25 individual missions as seen in Table 1. Most of the missions required video or photographic evidence; only one allowed a text-only response.

Table 1

GooseChase Mission List

\begin{tabular}{|l|l|c|}
\hline \multicolumn{1}{|c|}{ Name } & \multicolumn{1}{|c|}{ Description } & Points \\
\hline Open Me & $\begin{array}{l}\text { Take a photograph of 3 items you could use to help } \\
\text { open a jar or bottle. }\end{array}$ & 400 \\
\hline On the Perch & $\begin{array}{l}\text { Show an appropriate use for a perching stool, and } \\
\text { that you can seat the user on it safely. }\end{array}$ & 500 \\
\hline Extra Credit 2 & $\begin{array}{l}\text { Demonstrate the use of a piece of equipment not } \\
\text { included in the brief for any of the other missions. }\end{array}$ & 600 \\
\hline Walking Tall & $\begin{array}{l}\text { Demonstrate that you can set BOTH a walking frame } \\
\text { AND a pair of sticks at the correct height, and that } \\
\text { they can be used safely. }\end{array}$ & 600 \\
\hline Hoist-astic & $\begin{array}{l}\text { Take a photograph or video of you using one of the } \\
\text { house's hoists appropriately. }\end{array}$ & 1000 \\
\hline SI magic & $\begin{array}{l}\text { Take a photograph (captioned if necessary) showing } \\
\text { how you might use one piece of Sensory Integration } \\
\text { equipment. }\end{array}$ & 1000 \\
\hline $\begin{array}{l}\text { Clean \& } \\
\text { Fresh }\end{array}$ & $\begin{array}{l}\text { Demonstrate appropriate use of the upstairs shower } \\
\text { cubicle \& equipment. }\end{array}$ & 400 \\
\hline
\end{tabular}




\begin{tabular}{|c|c|c|}
\hline Name & Description & Points \\
\hline It's May Fair & $\begin{array}{l}\text { Show the correct use of a wheeled (Mayfair) } \\
\text { commode. }\end{array}$ & 500 \\
\hline $\begin{array}{l}\text { Dressing } \\
\text { Stick }\end{array}$ & Show 2 different uses of a dressing stick. & 400 \\
\hline Drink Up & $\begin{array}{l}\text { There are } 4 \text { different adapted cups / beakers. Show } \\
\text { the correct use of all } 4 \text {. }\end{array}$ & 600 \\
\hline Eat Up & $\begin{array}{l}\text { Take a unique photograph demonstrating the use of } \\
\text { some adaptive cutlery. Extra points are available for } \\
\text { unique entries. }\end{array}$ & 400 \\
\hline $\begin{array}{l}\text { Electrify that } \\
\text { Jar }\end{array}$ & Show the correct use of the electric jar opener. & 400 \\
\hline Extra Credit 1 & $\begin{array}{l}\text { Demonstrate the use of a piece of equipment not } \\
\text { included in the brief for any of the other missions. }\end{array}$ & 400 \\
\hline Legs Up & Show how you use a leg lifter. & 400 \\
\hline $\begin{array}{l}\text { Hand It to Me } \\
\text { on a Plate }\end{array}$ & Show the correct use of 2 different types of plate. & 500 \\
\hline $\begin{array}{l}\text { Sticky as a } \\
\text { Sticky Thing }\end{array}$ & $\begin{array}{l}500 \text { extra points are available for creative uses of } \\
\text { Dycem. }\end{array}$ & 500 \\
\hline $\begin{array}{l}\text { Toileting } \\
\text { Options }\end{array}$ & $\begin{array}{l}\text { Video evidence of the difference in use between a } \\
\text { Scandia, a Raised Toilet Seat (RTS) and a Free } \\
\text { Standing Toilet Frame (FSTF). }\end{array}$ & 400 \\
\hline Get Trollied & $\begin{array}{l}\text { Demonstrate that you can set the trolley to the } \\
\text { appropriate height for the user AND use it correctly. }\end{array}$ & 600 \\
\hline Toileting High & $\begin{array}{l}\text { Demonstrate appropriate fitting of a Raised Toilet } \\
\text { Seat. }\end{array}$ & 400 \\
\hline Sensorama & $\begin{array}{l}\text { Explain how the bed sensors (found in both beds) } \\
\text { might be used. }\end{array}$ & 500 \\
\hline Stairclimber & Demonstrate how you would safely use the stairlift. & 500 \\
\hline Sitting Pretty & $\begin{array}{l}\text { Demonstrate that you can raise the standard chair } \\
\text { safely. }\end{array}$ & 600 \\
\hline Sleep High & $\begin{array}{l}\text { Demonstrate that you can raise the standard bed (in } \\
\text { the front bedroom). }\end{array}$ & 1000 \\
\hline Sleepy Time & $\begin{array}{l}\text { Demonstrate how the profiling bed works - show that } \\
\text { you can sit someone up in bed and show how you } \\
\text { might use it to improve posture. }\end{array}$ & 1000 \\
\hline
\end{tabular}

The missions were ascribed a points value, with those expected to be more challenging or time-consuming worth a higher number of points. Students were assigned to teams of 3 people in order to promote active participation by all and were instructed to complete a minimum of 15 missions within the time available, although some students reported they felt this gave insufficient time. A written document was required to accompany each item and shared to form a collaborative "fact file" available to all students for future use. 
A collaborative learning approach combined aspects of social learning, experiential learning and inquiry-based learning to provide an appropriate pedagogy for the session (Higher Education Academy, Guild HE, \& Universities UK, 2011; Hollis \& Madill, 2006; Manca \& Ranieri, 2017). Students had already undertaken one clinical placement meaning that some would already have developed skills in equipment issue and fitting, whereas others may not have seen any equipment in practice at this stage. An element of peer-to-peer learning, defined by Boud, Cohen, and Sampson (1999) as a strategy in which "students learn with and from each other without the immediate intervention of a teacher" (p. 413), was anticipated and desired.

Learning outcomes for the session were:

1. To identify methods of improving independence through the prescription of small aids and equipment.

2. To critically evaluate the available equipment.

3. To use professional reasoning to justify equipment prescription based upon both need and occupational therapy theory.

The fact-file documents require four components to be filled in for the missions to be deemed complete. A small prize of sweets and chocolates was awarded for the winning team as an incentive.

1. Students were required to consider with whom the equipment might be used.

2. Students had to indicate which underlying theories might be relevant.

3. Students needed to list any contraindications to using the equipment.

4. Students were to identify any alternative equipment that might lead to the same outcome.

\section{BENEFITS AND CHALLENGES OF USE}

A 10-question survey (see Table 2) was used to assess student perception of the workshop. Students from the most recent cohort $(n=22)$ were invited to provide feedback approximately 6 months after the workshop with a response rate of $72 \%$ $(n=16)$. 
Table 2

Survey Questions

\begin{tabular}{|c|c|c|}
\hline No & Question & $\begin{array}{l}\text { Response } \\
\text { Options }\end{array}$ \\
\hline 1 & I found the session enjoyable & $\mathrm{Y} / \mathrm{N}$ \\
\hline 2 & $\begin{array}{l}\text { I think that I learned more about the equipment by } \\
\text { using the GooseChase app than I might have done } \\
\text { without }\end{array}$ & $\begin{array}{l}\text { Strongly agree / } \\
\text { Agree / } \\
\text { Disagree / } \\
\text { Strongly disagree }\end{array}$ \\
\hline 3 & $\begin{array}{l}\text { Taking photos was a distraction from the use of the } \\
\text { equipment }\end{array}$ & $\begin{array}{l}\text { Strongly agree / } \\
\text { Agree / } \\
\text { Disagree / } \\
\text { Strongly disagree }\end{array}$ \\
\hline 4 & $\begin{array}{l}\text { I felt more relaxed using the equipment without } \\
\text { the lecturer in the room }\end{array}$ & $\begin{array}{l}\text { Strongly agree / } \\
\text { Agree / } \\
\text { Disagree / } \\
\text { Strongly disagree }\end{array}$ \\
\hline 5 & I did not get enough support with the equipment & $\begin{array}{l}\text { Strongly agree / } \\
\text { Agree / } \\
\text { Disagree / } \\
\text { Strongly disagree }\end{array}$ \\
\hline 6 & I liked being able to see \& share the photographs & $\begin{array}{l}\text { Strongly agree / } \\
\text { Agree / } \\
\text { Disagree / } \\
\text { Strongly disagree }\end{array}$ \\
\hline 7 & $\begin{array}{l}\text { I can remember the session and some of the } \\
\text { equipment well }\end{array}$ & Agree / Disagree \\
\hline 8 & I have used the (written) Factfiles since the session & $\begin{array}{l}\text { A great deal / } \\
\text { a lot / } \\
\text { a moderate } \\
\text { amount / } \\
\text { a little / } \\
\text { not at all }\end{array}$ \\
\hline 9 & $\begin{array}{l}\text { I valued the opportunity to try the equipment out for } \\
\text { myself }\end{array}$ & $\mathrm{Y} / \mathrm{N}$ \\
\hline 10 & $\begin{array}{l}\text { I would like to make the following comments about the } \\
\text { session }\end{array}$ & Free text \\
\hline
\end{tabular}


Survey results demonstrated instant engagement with the learning activity and students entered into it with enthusiasm as shown in Figures 1 and 2. This did not appear to wane as the session progressed, suggesting that the game encouraged participation.
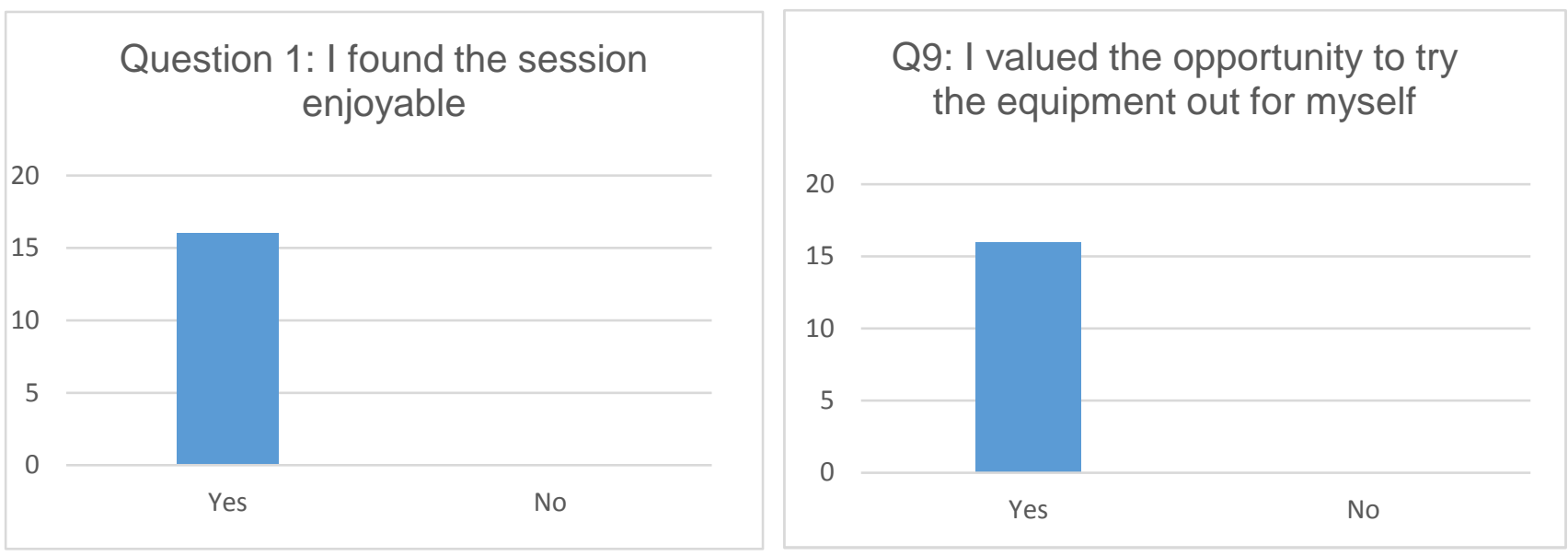

Figure 1. Survey response Q1.

Figure 2. Survey response Q9.

All students appeared to be equally involved in the activities. Most students were not distracted by the game (see Figure 3), although reactions to the sharing of photographs was mixed (see Figure 4), and the majority felt adequately supported (see Figure 5).

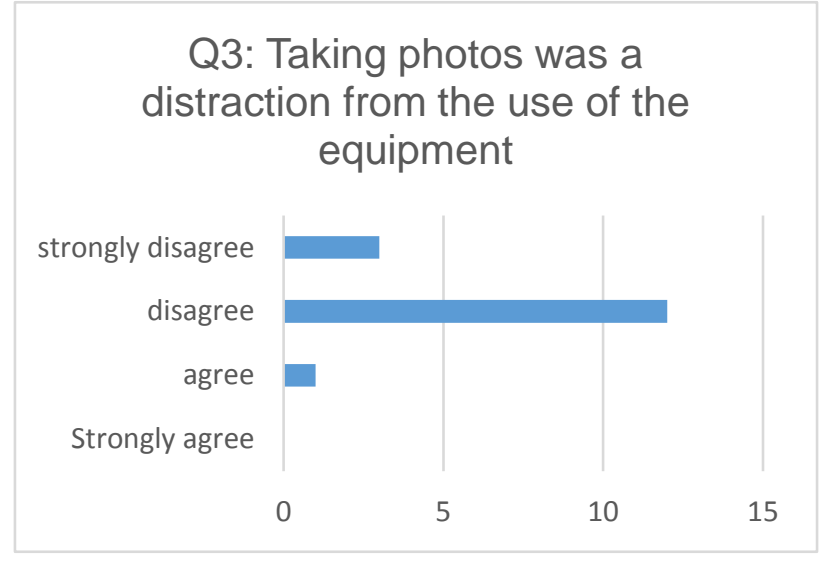

Figure 3. Survey response Q3.

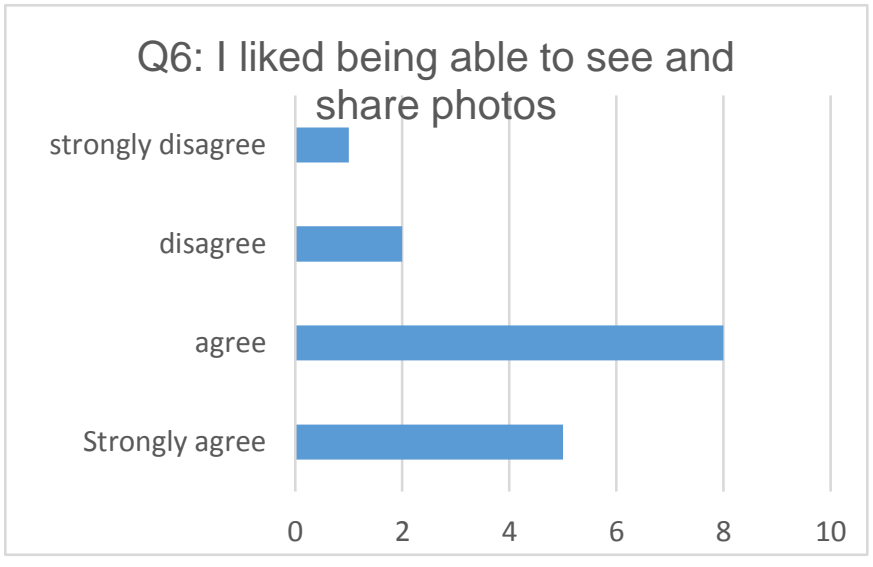

Figure 4. Survey response Q6. 


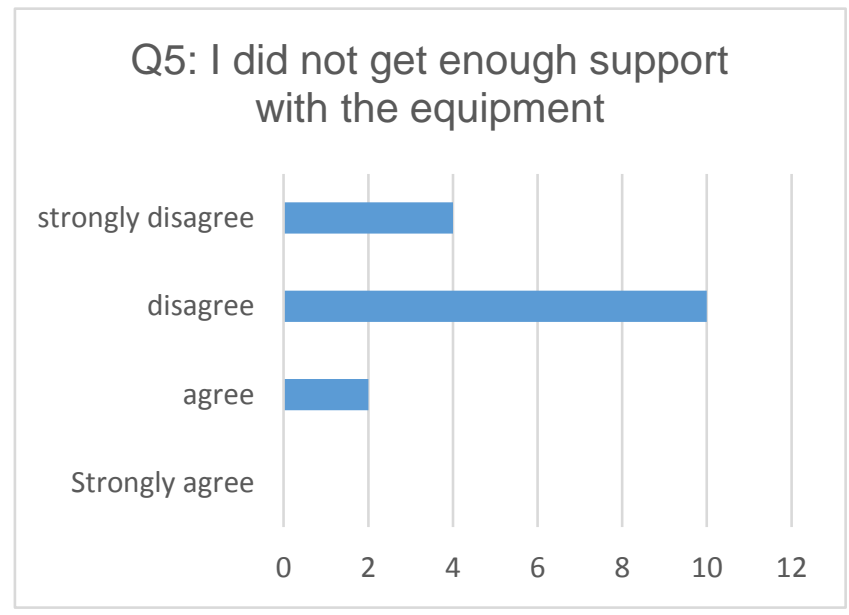

Figure 5. Survey response Q5.

Some inevitable problems occurred as the lecturer's expectations of the application's functionality were not met. For example, when giving the students instructions the lecturer had not realized that the video clip could only be 10 seconds long and that the photograph or video had to be taken within the application. This meant that students could not annotate or combine photos using other platforms such as Snapchat, as some students attempted. Such issues were quickly overcome, although it was noted that it would be good practice for staff to set up a mock game and engage with it as participants so that clearer instructions could be given to students in the future. With dependable internet connection in the classroom, there were few problems with uploading the data. However, the inability to send photos taken in an alternative program could lead this game to be frustrating in areas where the signal is less reliable. All students had access to a smartphone or tablet and had downloaded the application before the class. The game proved to be easy for the students to use and the live upload for the lecturer to review was beneficial. The game currently lacks a demonstration mode, so it is difficult to check how the game is going to work until it is launched, which was somewhat anxiety-provoking for the lecturer. Launching the game before the class began could give some students a feeling of advantage, and could cause anxiety to others, but is a possible solution.

Laurillard's (2010) assertion that developing high quality experiences is time consuming was not entirely recognized. While setting up the missions did take some time, it was a simple process and once the mission has been created it remains available to the user, so further missions can be added and old ones re-selected for future use. It was necessary to consider all of the equipment items available and generate an outcome (for example "show how to use...") that would demonstrate the students understood the benefits of each one. Ability House is home to over 100 pieces of equipment, so inevitably some were combined into one mission (i.e., take a photograph of 3 different jar openers) and others were not included at all. 
Staff involved in the process reported that the greatest and most unexpected benefit to learning came in the ability to download and review the students' submissions. This can be done as the task progresses, as the lecturer has access to a live feed of all the uploads, which was used to monitor safety. However, attempting to review all of the missions in detail could prevent the lecturer from being able to engage and answer student questions, and so time was scheduled after the class for this purpose.

Submissions were reviewed in detail and game points adjusted for accuracy and creativity. For example, groups who incorrectly fitted a raised toilet seat had points deducted, as did students who did not use the lap belt on the stairlift. This innovative method of providing feedback enhanced the game experience, one of the key benefits of game based learning (Crocco et al., 2016).

Reviewing the written documentation, in conjunction with the GooseChase photo submissions, enabled the teams to receive detailed feedback on their theoretical suggestions. Additional game points were awarded to teams who had attempted to explain the frame of reference guiding their use of a particular piece of equipment, or who had demonstrated critical thinking skills, leading to a richness of feedback with real consequences. Students reported finding the fact-files useful and many had referred to them since the session took place (see Figure 6). Figure 7 demonstrates that students could remember the session well despite the time which had since elapsed.

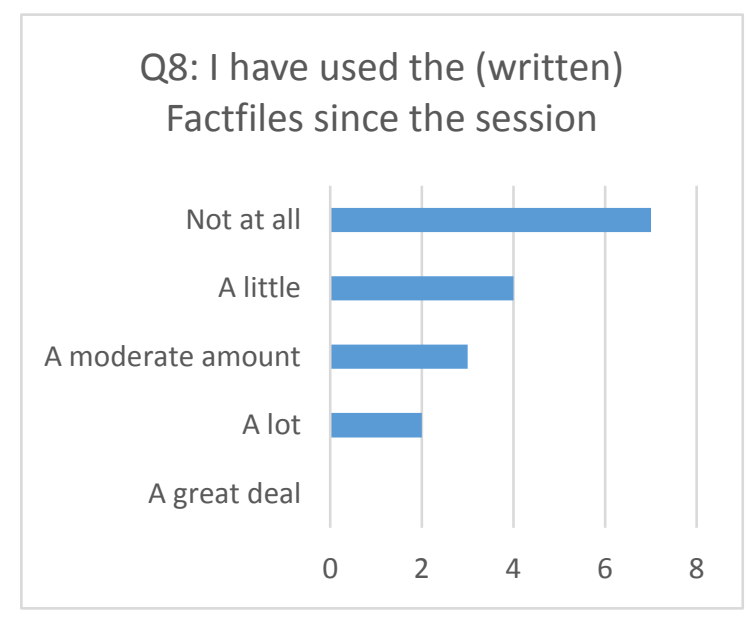

Figure 6. Survey response Q8.

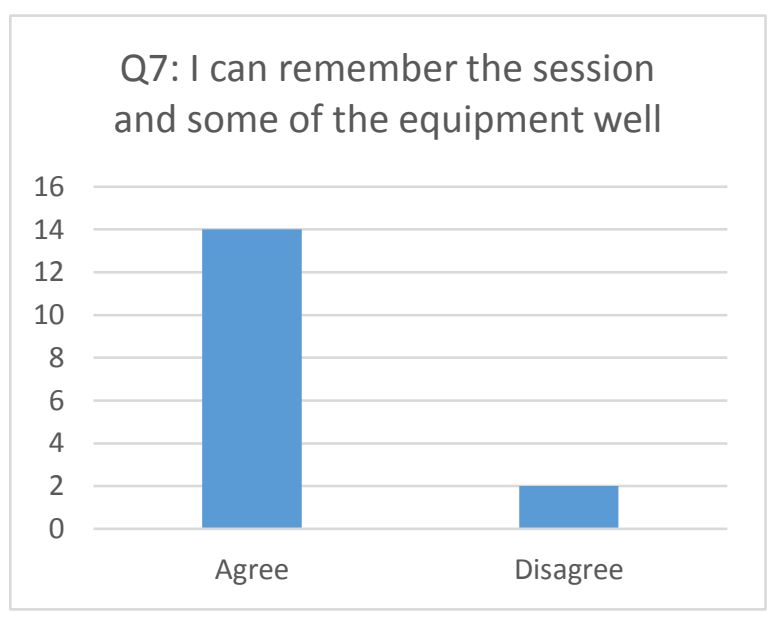

Figure 7. Survey response Q7.

It was noted that errors in practice, such as the incorrect fitting of raised toilet seats, were unlikely to be highlighted by a lecturer who moves from group to group offering support as required. There is a strong probability that these groups did not recognize that they needed help, and because toilet seat fitting is a low risk activity for students, the lecturer's time and attention could easily be overtaken by higher risk activities such as hoisting and using the stairlift. However, reviewing the photographs after the activity is complete enables feedback to be targeted to include smaller errors. Team scores, and therefore the much-coveted prize of a tub of chocolates to share, were awarded during the subsequent class and common or significant errors shared with the whole group for learning purposes. 
The ability to observe students without being in the room and therefore influencing their practice should not be underestimated. Video clips and photographs submitted by students demonstrate their final attempt at the practical task, thus enabling them to make mistakes and learn from one another before completing the final task. This fosters a culture of social learning and enables all students to be participants in the process and could be considered as an additional benefit of simulation previously unconsidered. The vast majority of students reported that they felt more relaxed without the lecturer in the room with them (see Figure 8) and all students reported feeling that they learned more with the application than they expected to have done without it (see Figure 9).

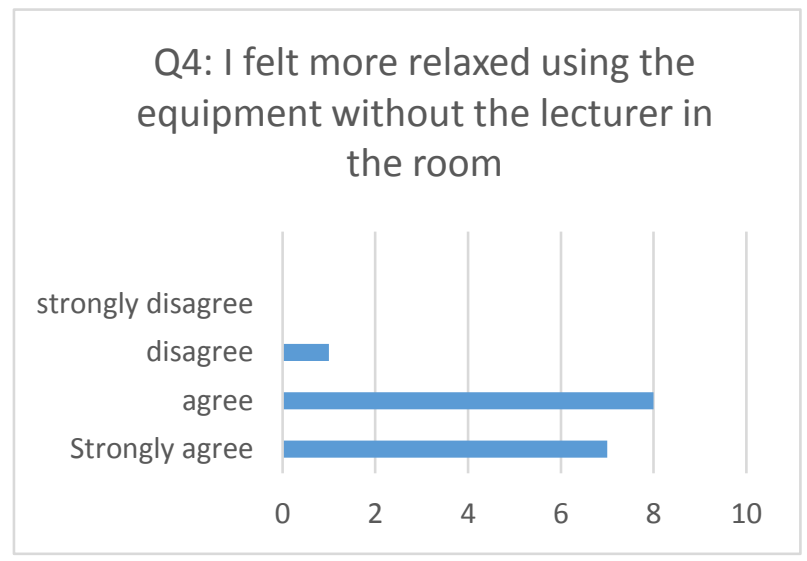

Figure 8. Survey response Q4.

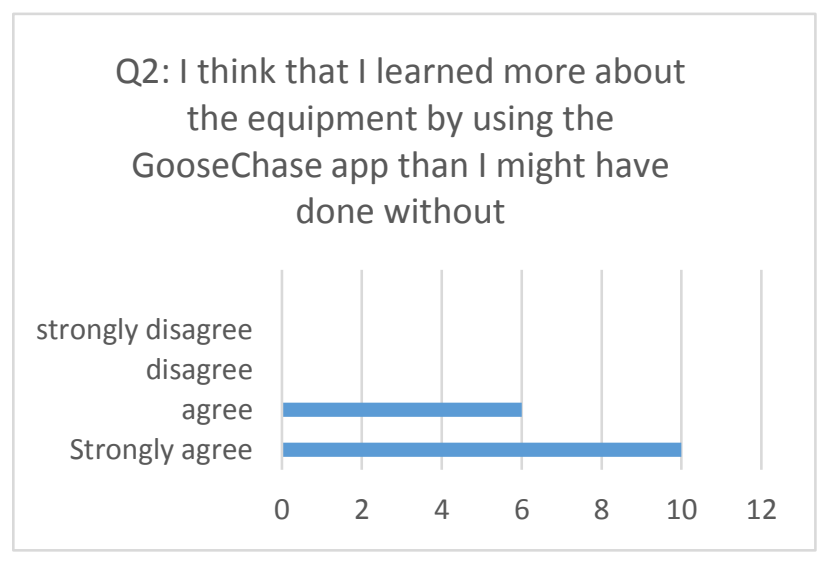

Figure 9. Survey response Q2.

Through increasing students' confidence with equipment via technology it is reasonable for clinicians to expect that students have had more exposure to and are more familiar with equipment than is currently the norm. There is potential for practice educators to state which equipment a student needs to be familiar with prior to placement starting, and for the student to practice using this equipment and submit their learning to the University lecturer for review prior to entering the practice environment. The technology could lend itself well to students being able to fully evidence competency which could, in turn, support greater independence in practice.

Most students remembered the session and the equipment well, and the vast majority have used the written fact-files in the months since the session. Qualitative responses from the students indicated that they enjoyed the experiences of autonomy and competition, stating "coming across a piece of equipment you may not be familiar with and trying to problem solve without a lecturer present first is a good learning experience" and "I enjoyed the practical nature of the activity and how it encouraged completion. This made the activity fun and engaging, and promoted teamwork." In addition, students remarked on the memorable nature of the session, with one student going as far as to say that "The practical and fun components brought an unforgettable learning experience while removing the pressure of getting it right, mistakes could be made without feeling like you were being marked or judged. Reflecting back I feel the information gained on that day is easily re-collectable because of the fun and practical elements." 


\section{IMPLICATIONS FOR OCCUPATIONAL THERAPY EDUCATION}

Using smartphone technology applications such as GooseChase to supplement practical learning can be of great benefit to students. In this example, it enabled the lecturer to craft a blended learning environment with aspects of social learning, experiential learning and enquiry-based learning which was authentic and relevant. Students enjoyed the game which led to high levels of engagement and memorability and there were some unexpected benefits in terms of identification of previously hidden errors. The ability to review the work after the class had finished enabled students to receive high quality, outcome-based feedback which they could re-visit to consolidate their skills. Time taken for setting up the game was offset by the repeatability.

With a growing emphasis on students as consumers (Bunce, Baird, \& Jones, 2017), GooseChase could facilitate the independent learning experiences of students by allowing them to learn without a lecturer needing to be in the room. This has wide ranging benefits including students learning at a time that best suits them - around the demands of work, placement and family life - without requiring a fixed session. It also supports problem-solving by the student, a skill which is required at the core of every occupational therapist, although safety management will need to be considered prior to students operating equipment unaided.

Finally, the memorability of such a fun learning experience ensures that learning is deeply embedded. All educators aspire to provide memorable experiences with a profound impact upon the student and GooseChase provides another tool with which this can be developed. There is potential for using this, or similar technology, for a wider range of skills such as manual handling, assessment skills and occupation analysis.

\section{References}

Bennett, S., Rodger, S., Fitzgerald, C., \& Gibson, L. (2017). Simulation in occupational therapy curricula: A literature review. Australian Occupational Therapy Journal, 64(4), 314-327. https://doi.org/10.1111/1440-1630.12372

Boland, P., Levack, W., Perry, M., \& Graham, F. (2017). Equipment provision after stroke: A scoping review of the use of personal care and mobility aids in rehabilitation. British Journal of Occupational Therapy, 80(2), 73-88. https://doi.org/10.1177/0308022616664910

Boud, D., Cohen, R., \& Sampson, J. (1999). Peer learning and assessment. Assessment and Evaluation in Higher Education, 24(4), 413-423. https://doi.org/10.1080/0260293990240405

Bunce, L., Baird, A., \& Jones, S. E. (2017). The student-as-consumer approach in higher education and its effects on academic performance. Studies in Higher Education, 42(11), 1958-1978. https://doi.org/10.1080/03075079.2015.1127908

Cordier, R., McAuliffe, T., Wilson, N. J., Totino, R., Dender, A., Smith, C., \& Stephens, M. (2016). The appropriateness and feasibility of an online e-portfolio for assessment of undergraduate allied health students. Australian Occupational Therapy Journal, 63(3), 154-163. https://doi.org/10.1111/1440-1630.12226 
Crocco, F., Offenholley, K., \& Hernandez, C. (2016). A proof-of-concept study of gamebased learning in higher education. Simulation \& Gaming, 47(4), 403-422. https://doi.org/10.1177/1046878116632484

Drummond, A., Whitehead, P., Fellows, K., Sprigg, N., Sampson, C., Edwards, C., \& Lincoln, N. (2013). Occupational therapy predischarge home visits for patients with a stroke (HOVIS): Results of a feasibility randomized controlled trial. Clinical Rehabilitation, 27(5), 387-397. https://doi.org/10.1177/0269215512462145

Frost, J., Isbel, S., Kellett, J., \& Lawlis, T. (2017). Using digital story telling to assess health students' knowledge of interprofessional roles in the care of the older adult. BMJ Simulation and Technology Enhanced Learning, 3(1), 5-8. https://doi.org/10.1136/bmjstel-2016-000136

Fry, H., Ketteridge, S., \& Marshall, S. (2003). A Handbook for Teaching \& Learning in Higher Education (2nd ed.). London: Kogan Page. https://doi.org/10.4324/9780203416877

Glenn, E. K., \& Gilbert-Hunt, S. (2012). New graduate occupational therapists experience of showering assessments: A phenomological study. Australian Occupational Therapy Journal, 59(3), 188-196. https://doi.org/10.1111/j.1440-1630.2012.01000.x

Hardy, S., Mushore, M., \& Goddard, L. (2016). Supporting student mental health nurses in clinical placement through virtual in-practice support (VIPS): Innovation uptake and the 'VIPS' project. Nurse Education Today, 46, 133-138. https://doi.org/10.1016/j.nedt.2016.08.033

Higher Education Academy, Guild HE, \& Universities UK. (2011). The UK Professional Standards Framework for teaching and supporting learning in higher education. Learning, 8. Retrieved from http://www.heacademy.ac.uk/ukpsf

Hollis, V., \& Madill, H. (2006). Online learning: The potential for occupational therapy education. Occupational Therapy International, 13(2), 31-78. https://doi.org/10.1002/oti.209

Laurillard, D. (2010). An approach to curriculum design. Education, (April), 1-35.

Manca, S., \& Ranieri, M. (2017). Implications of social network sites for teaching and learning. Where we are and where we want to go, Education and Information Technologies, 22, 605-622. https://doi.org/10.1007/s10639-015-9429-x

Murray, C., Turpin, M., Edwards, I., \& Jones, M. (2015). A qualitative meta-synthesis about challenges experienced in occupational therapy practice. British Journal of Occupational Therapy, 78(9), 534-546. https://doi.org/10.1177/0308022615586786

Murray, K., \& Ward, K. (2017). Attitudes to social media use as a platform for continuing professional development (CPD) within occupational therapy. Journal of Further and Higher Education, 41, 1-15. https://doi.org/10.1177/0308022615586786

Nicola-Richmond, K. M., Pépin, G., \& Larkin, H. (2016). Transformation from student to occupational therapist: Using the Delphi technique to identify the threshold concepts of occupational therapy. Australian Occupational Therapy Journal, 63(2), 95-104. https://doi.org/10.1111/1440-1630.12252 
O'Byrne, W. I., \& Pytash, K. E. (2015). Hybrid and blended learning: Modifying pedagogy across path, pace, time, and place. Journal of Adolescent \& Adult Literacy, 59(2), 137-140. https://doi.org/10.1002/jaal.463

Quality Assurance Agency for Higher Education. (2014). Education for Sustainable Development: Guidance for UK Higher Education Providers. Retrieved from https://www.heacademy.ac.uk/knowledge-hub/education-sustainabledevelopment-guidance-uk-higher-education-providers

Royal College of Occupational Therapists. (2012). Occupational Therapy for Adults Undergoing Total Hip Replacement / BAOT/COT. Retrieved from http://www.cot.co.uk/publication/cot-publications/occupational-therapy-adultsundergoing-total-hip-replacement

Rolls, K., Hansen, M., Jackson, D., \& Elliott, D. (2016). How health care professionals use social media to create virtual communities: An integrative review. Journal of Medical Internet Research, 18(6), e166. https://doi.org/10.2196/jmir.5312

Smeda, N., Dakich, E., \& Sharda, N. (2014). The effectiveness of digital storytelling in the classrooms: A comprehensive study. Smart Learning Environments, 1(1), 6. https://doi.org/10.1186/s40561-014-0006-3

Taub, M., Azevedo, R., Bradbury, A. E., Millar, G. C., \& Lester, J. (2018). Using sequence mining to reveal the efficiency in scientific reasoning during STEM learning with a game-based learning environment. Learning and instruction, 54, 93-103. https://doi.org/10.1016/i.learninstruc.2017.08.005

van Soeren, M., Devlin-Cop, S., MacMillan, K., Baker, L., Egan-Lee, E., \& Reeves, S. (2011). Simulated interprofessional education: An analysis of teaching and learning processes. Journal of Interprofessional Care, 25(6), 434-440. https://doi.org/10.3109/13561820.2011.592229

Verdonck, M., \& Maye, F. (2016). Enhancing occupational performance in the virtual context using smart technology. British Journal of Occupational Therapy, 79(6), 385-390. https://doi.org/10.1177/0308022615591172

Wilson, C. D., Reichsman, F., Mutch-Jones, K., Gardner, A., Marchi, L., Kowalski, S., ... Dorsey, C. (2018). Teacher implementation and the impact of game-based science curriculum materials. Journal of Science Education and Technology, 27, 285-305. https://doi.org/10.1007/s10956-017-9724-y

World Health Organization Centre for Health Development (n.d.) Assistive device. In H. Pyle (Ed.), Defined term: A glossary of terms for community health care and services for older persons. Retrieved from https://definedterm.com/a/document 